inheritance and regard the broad head as a dominant masking the long-headed Nordic element. A new theory has been put forward, or rather an old theory revived, in Germany, making the shape of the head fortuitous and eliminating its significance for the Nordic theory. Prof. Kruse of Leipzig, according to the Times of November 19, argues that the shape of the head depends upon whether babies are laid on soft or hard pillows. On soft pillows they lie on their backs and hence, he maintains, although originally long-headed, come to have broad heads as they grow. A broad head, therefore, is no disproof of Nordic ancestry. In the middle of the sixteenth century, Vesalius noted the difference between the rounded head of the Turk and the broad flat head of the German. The former he explained as due to the swathing of the head and the action of the midwife, and attributed the latter to the fact that German babies slept on their backs in their cradles, while the Belgians, sleeping on their sides, had longer heads. It is interesting to note that in Dürer's representations of German peasants at about the same date, the broad flat head is very marked.

\section{Academic Assistance Council}

LORD RUTHERFond's progress report of the Academic Assistance Council in a letter to the Times of November 16 is a statement in which the whole academic body of Great Britain may take legitimate pride. The Council, indeed, has not accomplished everything it would have wished; but its efforts nevertheless have effected much. Of the German scholars and men of science displaced since April 1933, Lord Rutherford says that 200 have found permanent places and 325 have been provided with temporary facilities for continuing their research outside Germany. In other words "at least two thirds of the whole number who were justified in looking to continue their scientific work have been assisted to remain in the academic world". Emergency grants have been given when needed and are still being given to 71 scholars and men of science while they are seeking posts. This is a remarkable achievement for an undertaking which was initiated in a period in which the whole world, and more especially the two countries which might be relied upon to respond generously to such an appeal, namely, Great Britain and the United States, were in a state of economic depression without a parallel. The need for effort, however, still remains, for the funds available for meeting present commitments will be exhausted in July 1935. Further, while Lord Rutherford is in a position to state that the work of the Council has now attained a basis of international co-operation, this announcement, unfortunately, coincides with a report of the financial collapse of national committees on the Continent.

LORD RUTHERFORD goes on to outline a further objective. The size and nature of the problem with which the Council has had to deal hitherto is now definitely known; and it is proposed to add to the functions of the Council the formation of a trust for creating a number of research fellowships which will be available for scholars and men of science of special distinction, who are debarred from carrying on their work in virtue of their race, religion or political opinions. These fellowships will be awarded irrespective of nationality. It will be remembered that, although the work of the Academic Assistance Council has necessarily been directed to the alleviation of the difficulties of those who have suffered through the political situation in Germany, the purpose of those by whom the Council was founded is to assist any, of whatever nationality, who might be dispossessed on such grounds. The same principle will be applied in the award of the proposed research fellowships. Already Lord Rutherford has been able to announce the prospect of a contribution from America which will provide for 36 research fellowships tenable for a period of three years in any of the universities within the British dominions. This generous offer will no doubt stimulate other contributions. Should the proposal of the Council come to full fruition on a pan-national basis, it will confer upon it a unique position as a permanent international rallying point for the defence of academic freedom-a consummation eminently to be desired in the present trend of world conditions.

\section{University Education}

IN his inaugural address to the Royal Statistical Society on November 20, the president, Prof. Major Greenwood, discussed the "Recent History and Function of University Education". Speaking of the statistical changes in the proportion of males in England and Wales who have entered upon a university course since 1801, Prof. Greenwood estimated that at the beginning of the nineteenth century, when Oxford and Cambridge were the only English universities, about one-half per cent of males had a university education, a very slightly larger proportion at the middle of the nineteenth century and now about 2 per cent. In Germany, before the Nazi regime, it was estimated that not more than 3 per cent of university students came from working class families. It is unlikely that the proportion is more than 10 per cent in England and Wales. An author writing in the first volume of the Society's Journal estimated that the universities of Great Britain had a total revenue in 1831 of $£ 800,000$ per annum; in 1931-32 their total income was $£ 5,874,778$, of which more than $£ 2,000,000$ came from Parlia. mentary grants.

THE renaissance of English university education which began rather more than eighty years ago led to a discussion of the functions of a university to which Cardinal Newman, Mark Pattison and Walter Bagehot all contributed; their views, however different the expressions, were essentially similar, namely, that higher education in its highest and best sense implied segregation; "a university should be situated," said Pattison, "like the poet's garden, 'Not wholly in the busy world, nor quite beyond it'." Prof. Valentine has recently shown that in universities now, even among scholarship entrants, a sensible proportion (in the modern provincial universities) fail 